\title{
GREEN BOUGHS WILL COVER THEE
}

\author{
Sibling rivalry.
}

\section{BY SARAH L BYRNE}

$\mathrm{D}$ on't judge me too harshly, little girl. It's April and the scent of the lilacs reminds me it would soon be your birthday. As if I would ever forget.

April was her birthday, although 'birth' wasn't how I made her, and 'day' meant nothing to her, with her chronobiology synchronized to standard temporal units. Still, she had a birthday. She was a person.

June, and the world was green, that perfect budding green that lasts only weeks before the Sun and the wind start to fade its freshness. She was perfect. The day she curled her apical meristem around my finger, I knew she knew me.

July. How she grew, shooting up so fast. Some days I thought I could see her growing before my eyes; spreading, twining. I couldn't look away in case I missed something, didn't want to affect the bonding by leaving her alone. I started to sleep in the lab. You had your nanny, didn't you, to watch you in our quarters? You had friends from school, homework to do. She was only a baby; she needed me more.

August: the harvest time, the haymaking. I should have known what was coming. But it's a hazy dreamlike time, the hay bales lie like sleeping giants in the fields and it's easy to forget how death looks like sleep from a far enough distance.

October. You'd have loved October; that first day every year when you step outside and there's a chill in the air and a bit of a misty drizzle and the smoke of a garden bonfire drifting on the breeze.

I skipped September. I know. I don't want to go back to September.

It's all lies, anyway. I lied about April, about the lilacs. There are no flowers here, no summer haze or rainy days or leaves burning in the fog. Only a metal hull for the sky and a climate-controlled life-support system that makes every day the same. There are no seasons here. But I always made sure to keep count, to tell you the stories, so you'd know the rhythms, the seasons; your

$\rightarrow$ NATURE.COM

Follow Futures:

y @NatureFutures

$f$ go.nature.com/mtoodm ancestry. So you'd recognize home when we got there. The rhythms matter.

September, then. I'd been so busy with her. She was still growing fast, too fast; the regulatory mechanisms weren't working and I couldn't figure out why. They were starting to talk about destruction protocols, and I couldn't let that happen, had to find a way to save her. You came looking for me, and I told you ...
December, the darkest hour before the dawn, before the Sun is born, a son is born. But I had only daughters. All your life we were heading for the Sun, our survey among the stars was done and we were going home. You were born so far from home, and that's why the stories mattered. We were getting so close when September came.

November: the year heading inexorably into darkness. You'd been gone two months and we were approaching orbit, close enough that they'd take you home after all. But I wouldn't be with you. We decided that in October.

We did October already, didn't we? The mist and the bonfires. The day they said she was dangerous, invasive; she'd never be permitted to leave the ship. I couldn't leave her all alone in the cold emptiness of space. Not after you. Not after September.

September. I didn't know you'd do it. I would have run after you if I'd known, would have wrapped you in my arms like I could have you safe inside me again, because it wasn't true, it could never be true; I could never have loved anyone more than you.

But you had my temper, and I let you go. Eight years old; you couldn't have known what would happen when you tried to shut down the systems that fed her. When you slammed the door of the bio-lab control room behind you and ripped out the tubing that supplied her carbon dioxide. You couldn't have known that the gas would flood that sealed space; that what nourished her would suffocate you; that when they found you it would be too late and it would never be April again.

Forgive me, little girl, my little May. For staying with her, for not being there to watch the lilacs bloom over your grave. She twines around my wrists like chains now; she spreads through empty walkways and abandoned quarters, always hungry, always growing. But she's all I have left of you.

She's your sister.

Sarah L. Byrne is an editor and writer in London. Her short speculative fiction and freelance science writing can be found at http://sarahbyrne.org. 